\title{
Colon adenoma and adenocarcinoma with clear cell components - two case reports
}

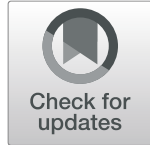

\author{
Yuzo Oyama ${ }^{1}$, Haruto Nishida ${ }^{1 *}$ (D), Takahiro Kusaba ${ }^{1}$, Hiroko Kadowaki ${ }^{1}$, Motoki Arakane ${ }^{1}$, Kazuhisa Okamoto², \\ Junpei Wada ${ }^{3}$, Shogo Urabe ${ }^{3}$ and Tsutomu Daa ${ }^{1}$
}

\begin{abstract}
Background: Diagnoses reflect clear cell morphologies when tumor cells have clear cytoplasm in many organs, and the nature of such clear cells is typically identified. Colorectal tubular adenoma or adenocarcinoma, conversely, rarely show clear cells, the reason for which remains uncertain. We report 2 colon tumors with clear cell components (Case 1: adenoma; Case 2: adenocarcinoma) and investigate the nature of the clear cells.

Case presentation: Case 1 was a 75-year-old man with a superficial elevated polyp detected in the rectum for whom endoscopic submucosal dissection was performed. Microscopically, 10\% of the tumor showed dysplastic columnar epithelium with clear cytoplasm forming tubular structures accompanied by conventional tubular adenoma. Case 2 was a 58-year-old man with a pedunculated polyp found in his sigmoid colon for which polypectomy was performed. Microscopically, $90 \%$ of the tumor showed dysplastic columnar epithelium with clear cytoplasm forming fused glands or cribriform structures adjacent to the ordinal tubular adenocarcinoma. In both cases, clear and ordinary tumor cells were negative for CK7 and positive for CK20 and CDX2, consistent with findings of colorectal origin. Different results were found for CEA and CD10 staining. CEA was positive on the luminal side of the conventional area in contrast diffuse cytoplasmic staining of the clear cell area in both cases. CD10 was only positive for the clear cell component of case 2 . The clear cell components were negative for Periodic acid-Schiff (PAS), Alcian blue, and mucicarmine staining and AFP immunohistochemistry. An ultrastructural examination found multiple cytoplasmic lipid-like vacuoles in the clear cell component that were predominantly negative for adipophilin by immunoelectron microscopy.

Conclusions: We investigated tubular adenoma and tubular adenocarcinoma with clear cell components. The accompanying conventional tubular adenoma or adenocarcinoma cells helped us to evaluate the atypia of the clear cells. Diffuse cytoplasmic staining of CEA and CD10 suggested that the clear cell component might harbor malignant potential. We were unable to verify the well-known causes of clear cytoplasm, such as an accumulation of glycogen, lipid, or mucin and enteroblastic differentiation. The causes of clear cells in the colorectal region remain uncertain; however, possible explanations include autolysis and carbohydrate elution.
\end{abstract}

Keywords: Colon, Adenocarcinoma, Clear cell change, Electron microscopy

\section{Background}

In many organs, including the ovary, uterus, kidney, salivary gland, thyroid gland, skin, and breast, when tumor cells show clear cytoplasm, the diagnoses reflect the clear cell morphology, such as clear cell adenocarcinoma (CCA), clear cell carcinoma, glycogen-rich adenocarcinoma, lipid-rich adenocarcinoma, and other clear cell

\footnotetext{
* Correspondence: nharuto@oita-u.ac.jp

${ }^{1}$ Departments of Diagnostic Pathology, Faculty of Medicine, Oita University,

1-1, Idaigaoka, Hasama-machi, Yufu City 879-5593, Japan

Full list of author information is available at the end of the article
}

variants of each tumor [1]. These diagnoses tend to be used when the clear cell nature of the tumor is evident [1]. In colorectal tubular adenoma or adenocarcinoma, conversely, clear cells are rarely observed, the reason for which remains uncertain [2-26]. Herein, we report an additional case of tubular adenoma and of tubular adenocarcinoma, both of which have a clear cell component. We describe a thorough investigation of its clear cell etiology and review the literature.

(c) The Author(s). 2019 Open Access This article is distributed under the terms of the Creative Commons Attribution 4.0 International License (http://creativecommons.org/licenses/by/4.0/), which permits unrestricted use, distribution, and 

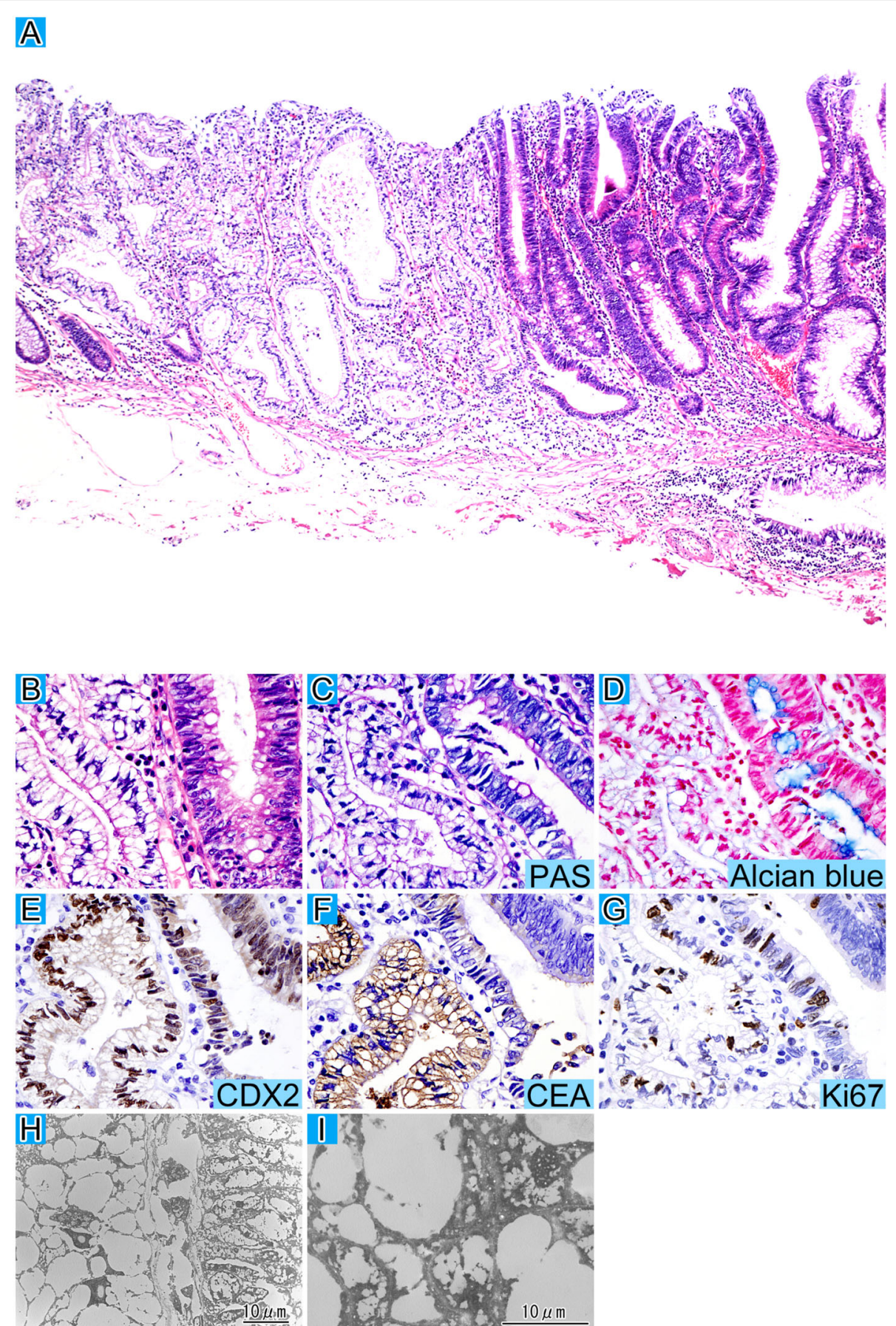

Fig. 1 Tubular adenoma with clear cell change. The striking tubule structures of the clear cells are accompanied by conventional tubular adenoma cells at low magnification with HE staining (a). The boundary between the clear cell and conventional components at high magnification with HE staining (b). The clear cell component is negative for PAS (c) and alcian blue staining (d). Both components are positive for CDX2 staining (e). The localization of CEA (f) expression is diffusely cytoplasmic for the clear cell component, and luminal cell apical for the conventional one. Ki67 labeling $(\mathbf{g})$ is slightly lower in the clear cell component. $d$-g represent immunohistochemistry. Ultrastructural examination (h) of the boundary between the clear cell area (left) and the conventional adenoma (right) at low magnification is shown and multiple cytoplasmic lipid-like vacuoles surround the nuclei in the clear cells (i) 


\section{Case presentation}

\section{Case 1}

A 75 years old man with a past history of gastric cancer was introduced to Oita Prefectural Hospital for a routine colonoscopy examination. An $18 \times 12 \mathrm{~mm}$ superficial elevated polyp was detected in the rectum and resected endoscopically.

Microscopically, 90\% of the tumor cells showed dysplastic columnar epithelium with hyperchromatic short spindle nuclei regularly arranged in the basal portion and eosinophilic cytoplasm (Fig. 1a and b). We diagnosed it as conventional tubular adenoma with low grade dysplasia. Additionally, $10 \%$ of the tumor cells had dysplastic columnar epithelium with randomly arranged pyknotic polygonal nuclei and clear cytoplasm (Fig. 1a and $b$ ).

Periodic acid-Schiff (PAS), PAS diastase (PAS-D), Alcian blue, and mucicarmine staining were all negative for the clear cell component (Fig. 1c and d). The antibodies used in this study are listed in Table 1. Immunohistochemically, both tumor components were negative for CK7, focally positive for CK20, and positive for CDX2 (Fig. 1e). A difference in results was observed following staining for carcinoembryonic antigen (CEA) (Fig. 1f). Positive CEA staining was found on the luminal side in the conventional area of the tumor; however, diffuse cytoplasmic staining was observed in the clear cell area. MUC2, MUC5AC, MUC6, CD10, AFP, $\mathrm{AR}$, perilipin, and adipophilin were all negative for clear cell components. The Ki67 (Fig. 1g) labeling index (LI) was 83.7 and $73.8 \%$ for conventional and clear cell components, respectively. Electron microscopic examination found multiple lipid-like vacuoles in the clear cell component but not in the conventional component (Fig. 1h and i). He received regular follow-up and did not have a recurrence for 4 years.

\section{Case 2}

A 58-year-old man was admitted to Oita University Hospital for the medical examination of an abnormality. The contrast CT examination showed a wall thickness of the sigmoid colon and a colonoscopy was performed. There were multiple polyps detected in the sigmoid colon and a $25 \mathrm{~mm}$ in size pedunculated polyp was endoscopically resected. Microscopically, $10 \%$ of the tumor cells were conventional tubular adenocarcinoma with hyperchromatic oval nuclei regularly arranged in the basal portion and eosinophilic cytoplasm (Fig. 2a, b, c, and d). The other tumor cells displayed dysplastic columnar epithelium with large epithelioid or polygonal nuclei randomly arranged and clear or vacuolated cytoplasm, showing cribriform or fused tubular structures and desmoplastic reaction was seen in the surrounding stroma (Fig. 2b). These findings were thought to be invasion. Tumor invaded into submucosa (pT1b).

PAS, PAS-D, Alcian blue, and mucicarmine staining were all negative for the clear cell component (Fig. 2e and f). Immunohistochemically, both tumor components were negative for CK7, focally positive for CK20, and positive for CDX2 (Fig. 2g) and MUC2. The differences

Table 1 Antibody information

\begin{tabular}{|c|c|c|c|c|}
\hline Antibody & Clone & Company & Dilution & Conditioning \\
\hline CK7 & OV-TL 12/30 & DAKO, Santa Clara, USA & $1: 50$ & Protease \\
\hline CK20 & Ks 20.8 & DAKO, Santa Clara, USA & $1: 50$ & Protease \\
\hline $\mathrm{CDX} 2$ & AMT28 & Novus Biologicals, Newcastle, UK & $1: 50$ & $\mathrm{pH} 9.0$ \\
\hline CEA & $\|-7$ & DAKO, Santa Clara, USA & 1:40 & $\mathrm{pH} 6.0$ \\
\hline CD10 & $56 C 6$ & Novocastra, Newcastle, UK & $1: 50$ & pH 6.0 overnight \\
\hline MUC2 & Ccp58 & Novocastra, Newcastle, UK & $1: 100$ & $\mathrm{pH} 6.0$ \\
\hline MUC5AC & $\mathrm{CLH} 2$ & Abcam, Cambridge, UK & $1: 1000$ & \\
\hline MUC6 & $\mathrm{CLH} 5$ & Novocastra, Newcastle, UK & $1: 100$ & $\mathrm{pH} 6.0$ \\
\hline AFP & N1501 & DAKO, Santa Clara, USA & diluted & \\
\hline Glypican3 & $1 \mathrm{G} 12$ & Nichirei Bioscience, Tokyo, Japan & diluted & $\mathrm{pH} 9.0$ \\
\hline$A R$ & AR441 & DAKO, Santa Clara, USA & $1: 25$ & $\mathrm{pH} 6.0$ \\
\hline Perilipin & GP29 & PROGEN, Heidelberg, Germany & $1: 200$ & $\mathrm{pH} 6.0$ \\
\hline Adipophilin & AP125 & Acris Antibodies, Herford, Germany & $1: 10$ & $\mathrm{pH} 6.0$ \\
\hline Ki67 & MIB-1 & DAKO, Santa Clara, USA & $1: 50$ & $\mathrm{pH} 6.0$ \\
\hline $\operatorname{cox} 2$ & CX-294 & DAKO, Santa Clara, USA & $1: 100$ & $\mathrm{pH} 9.0$ \\
\hline APC & CC-1 & Oncogene, California, USA & $1: 20$ & $\mathrm{pH} 6.0$ \\
\hline
\end{tabular}

CK Cytokeratin, CDX2 Caudal type homeobox 2, CEA Carcinoembryonic antigen, CD Cluster differentiation, MUC Mucin, AFP Alpha fetoprotein, AR Androgen receptor, COX2 Cyclooxygenase 2, APC Adenomatous polyposis coli 


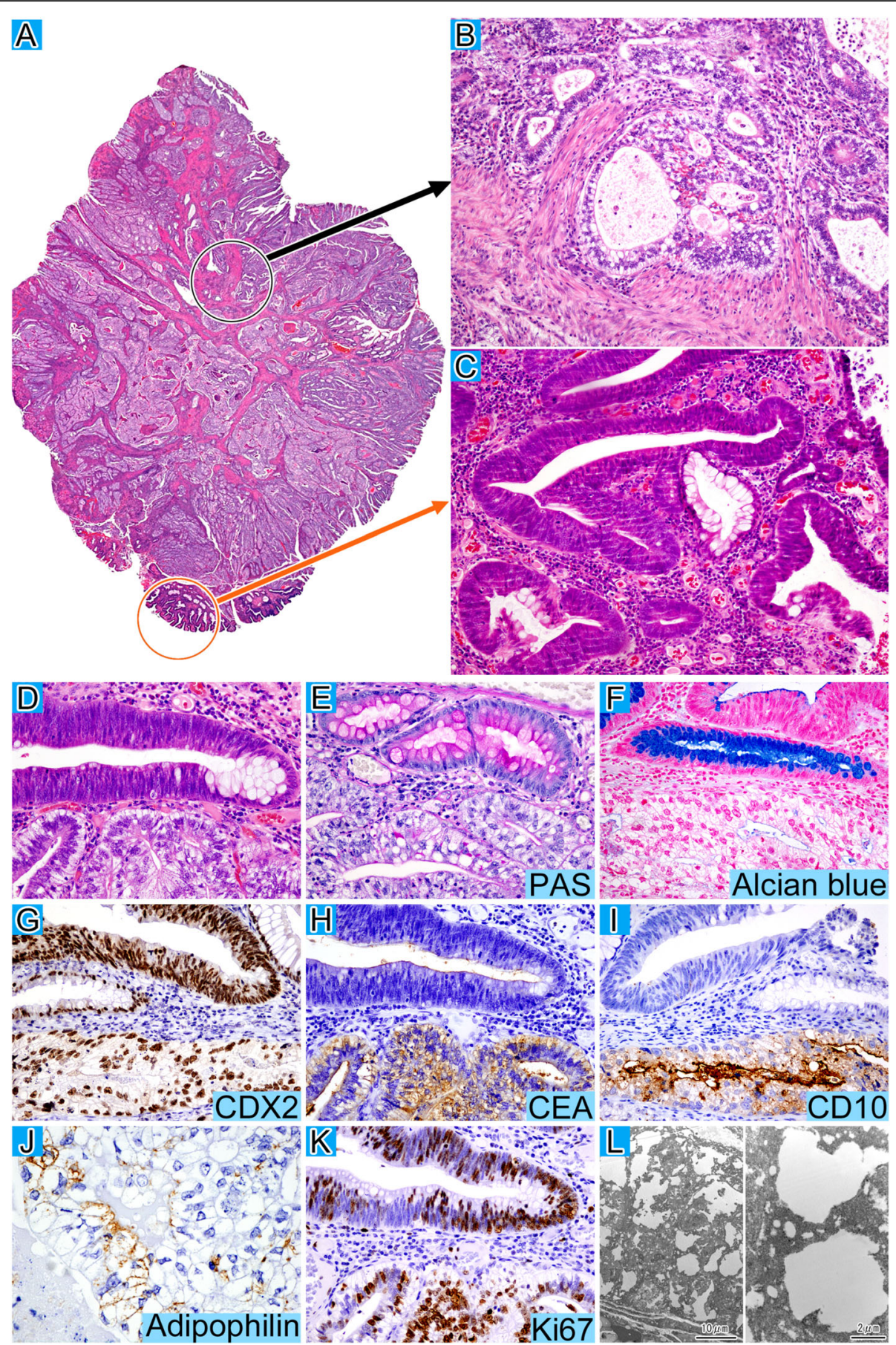

Fig. 2 Clear cell adenocarcinoma. Low magnification (a) and high magnification of the clear cell (b) and conventional components (c) with HE staining. The boundary (d) between the clear cell and conventional components at high magnification with HE staining. The clear cells are negative for PAS (e) and alcian blue staining (f), whereas both components of the tumor are positive for CDX2 (g). The localization of CEA (h) expression is diffusely cytoplasmic for the clear cell component and luminal cell apical for the conventional component. CD10 (i) and adipophilin (j) expression is confined to the clear component and Ki67 labeling (k) is higher in the clear cell component. g-k represent immunohistochemistry. Immunoelectron microscopy analysis (I) at low (left) and high magnification (right) reveals multiple cytoplasmic lipid-like vacuoles in clear cells that are negative for adipophilin

in results between the two components were staining for CEA (Fig. 2h) and CD10 (Fig. 2i). Positive CEA staining was observed for the luminal aspect in the conventional component; however, there was diffuse cytoplasmic staining in the clear cell component. CD10 was only positive for the clear cell part and adipophilin (Fig. 2j) 
Table 2 Clinicopathological information for 20 colorectal adenomas with clear cell components

\begin{tabular}{|c|c|c|c|c|c|c|c|}
\hline Author $^{\text {Ref }}$ & Age & Sex & Location & Size (cm) & PAS & Alcian blue & Prognosis \\
\hline Reed et al. [2] & $\mathrm{ND}$ & ND & ND & ND & ND & $\mathrm{ND}$ & \\
\hline Jewell et al. [3] & 61 & $\mathrm{~F}$ & $\mathrm{R}$ & 2 & - & - & Alive \\
\hline Suzuki et al. [4] & 62 & M & D & 1.4 & - & - & Alive \\
\hline \multirow[t]{3}{*}{ Domoto et al. [5] } & 54 & M & $S$ & 6 & - & Scattered & \\
\hline & 45 & M & T & 6 & - & Scattered & \\
\hline & 44 & M & S & 10 & - & Scattered & \\
\hline \multirow[t]{3}{*}{ Eloy et al. [6] } & 48 & $\mathrm{~F}$ & $\mathrm{~T}$ & 2.5 & ND & - & \\
\hline & 68 & $\mathrm{~F}$ & S & 0.5 & ND & - & \\
\hline & 84 & M & S & 1.8 & ND & - & \\
\hline \multirow[t]{8}{*}{ Shi et al. [7] } & ND & ND & ND & 0.8 & ND & ND & \\
\hline & 61 & M & S & 1.5 & ND & ND & \\
\hline & ND & ND & ND & 1.8 & ND & ND & \\
\hline & 63 & $\mathrm{~F}$ & As & 0.5 & - & ND & \\
\hline & 63 & M & $\mathrm{R}$ & 1.4 & - & ND & \\
\hline & 68 & $\mathrm{~F}$ & ND & 3.5 & - & ND & \\
\hline & 30 & $\mathrm{~F}$ & S & 1.4 & - & ND & \\
\hline & 35 & M & $S$ & 1.3 & ND & ND & \\
\hline Yao [8] & 48 & M & S & 0.8 & - & - & \\
\hline Miyasaka et al. [9] & 63 & M & $A s, D, R$ & ND & - & - & \\
\hline Present study & 75 & M & $\mathrm{R}$ & 1.8 & - & - & Alive \\
\hline
\end{tabular}

$M$ Male, $F$ Female, As Ascending colon, $T$ Transverse colon, $D$ Descending colon, $S$ Sigmoid colon, $R$ Rectum, ND No data

was only focally positive for clear cell component. MUC5AC, MUC6, AFP, glypican 3, perilipin, and AR were all negative. COX2 and APC were weakly diffuse cytoplasmic staining for both components, but the staining of APC seemed to attenuate or disappear in invasive areas. The Ki67 LI (Fig. 2k) was $80.0 \%$ and almost $100 \%$ for conventional and clear cell components, respectively. An immunoelectron microscopic examination was performed according to procedures described in a previous study [27] and showed that the nuclei were surrounded by multiple cytoplasmic lipid-like vacuoles similar to case 1 and they were mostly negative for adipophilin (Fig. 2l). Postoperative follow-up testing such as a laboratory examination, CT imaging, and endoscopic examination didn't show any sign of recurrence and he was free from the disease for 1 year and a half.

\section{Discussion and conclusions}

A clear cell colorectal tumor was first described by Hellstrom's report of a physaliferous variant of colon adenocarcinoma [10]. Clear cells were then detected in colorectal tubular adenoma, hyperplastic polyps, and tubular adenocarcinoma [2-9]. Domoto et al. [5] retrospectively analyzed the probability of clear cell tubular adenoma and its incidence was only $0.086 \%$.
To date, there have been 44 cases of clear cell of colorectal epithelial tumors reported, composed of 20 adenomas (Table 2) and 24 adenocarcinomas (Table 3) [226]. The median age was 57.2 and 58.6 years for adenoma and adenocarcinoma, respectively. Both tumors showed a male predilection (adenoma: 11/17, adenocarcinoma: 18/23) and occurred mostly in the left-side colon (adenoma: 14/19, adenocarcinoma: 16/24). Some cases had multiple polyps at the same time $[3,7,9,11$, $14,16,20]$ and two cases had multiple tubular adenomas with a clear cell component [7, 9]. Case 2 reported here had multiple polyps; however, no other polyps had clear cell components.

Histologically, the clear cells of colorectal tumors characteristically have pyknotic polygonal nuclei not confined to the basal portion but randomly arranged and clear or vacuolated cytoplasm [5]. In our cases, it was difficult to assess the nuclear atypia of clear cells, however, conventional tubular adenoma or adenocarcinoma cells accompanied them and there was a transition between both components. This helped us to recognize the clear cell components as the atypical equivalent to adenoma or adenocarcinoma. Moreover, it may be misleading to diagnose metastatic carcinoma if the clear cell component accounts for the vast majority of the tumor. Therefore, it is important to confirm a colorectal origin 
Table 3 Clinicopathological information for 24 colorectal adenocarcinomas with clear cell components

\begin{tabular}{|c|c|c|c|c|c|c|c|}
\hline Author Ref & Age & Sex & Location & Size $(\mathrm{cm})$ & PAS & Alcian blue & Prognosis \\
\hline Hellstrom and Fisher [10] & 67 & M & $\mathrm{R}$ & 2 & $-1+$ & - & Alive \\
\hline Reed et al. [2] & 71 & M & T & 7 & + & & ND \\
\hline \multirow[t]{2}{*}{ Jewell et al. [3] } & 75 & M & S & 0.1 & - & - & Died \\
\hline & 56 & $\mathrm{~F}$ & $S$ & 6 & ND & - & ND \\
\hline Watson [11] & 58 & M & $A C$ & 3.5 & + & - & Died \\
\hline Rubio [12] & 68 & M & D & 6 & $-/+$ & - & Died \\
\hline Furman and Lauwers [13] & ND & ND & $\mathrm{R}$ & ND & + & ND & ND \\
\hline Braumann et al. [14] & 89 & M & T & 2.2 & - & - & Died \\
\hline Mallik and Katchy [15] & 36 & $\mathrm{~F}$ & $\mathrm{R}$ & 5 & + & + & ND \\
\hline Ko et al. [16] & 62 & M & S & 1.5 & ND & ND & ND \\
\hline Hao et al. [17] & 37 & M & $\mathrm{D}$ & 12 & + & - & Alive \\
\hline Barisella et al. [18] & 54 & M & As & 0.9 & ND & ND & Alive \\
\hline Soga et al. [19] & 71 & $\mathrm{~F}$ & S & 0.8 & - & - & ND \\
\hline Bressenot et al. [20] & 84 & $\mathrm{~F}$ & $\mathrm{D}$ & 3.5 & - & - & Alive \\
\hline \multirow[t]{2}{*}{ Shi et al. [7] } & 52 & M & $\mathrm{R}$ & 0.9 & - & ND & ND \\
\hline & 51 & M & S & 1.4 & - & ND & ND \\
\hline Furuya et al. [21] & 81 & M & As & 9.5 & + & ND & Died \\
\hline Barrera-Maldonado et al. [22] & 41 & $\mathrm{~F}$ & D & 3.4 & ND & ND & ND \\
\hline Wang et al. [23] & 26 & M & T & 12 & ND & ND & Died \\
\hline Thelin et al. [24] & 25 & M & As & 3 & ND & ND & Died \\
\hline \multirow[t]{2}{*}{ Remo et al. [25] } & 58 & M & As & 7 & ND & ND & Died \\
\hline & 79 & M & As & 4.5 & ND & ND & Died \\
\hline Tochio et al. [26] & 48 & M & D & 0.7 & - & - & Alive \\
\hline This study & 58 & M & S & 2.5 & - & - & Alive \\
\hline
\end{tabular}

$M$ Male, $F$ Female, As Ascending colon, $T$ Transverse colon, $D$ Descending colon, $S$ Sigmoid colon, $R$ Rectum, AC Anal canal, ND No data

by immunohistochemical analysis of CK7, CK20, and CDX2 [7]. Our cases were CK7 negative, CK20 focally positive, and CDX2 diffusely positive, consistent with a colorectal origin.

Differences in staining results between the conventional and clear cell component were found for CEA and CD10. The localization of CEA is associated with tumor differentiation; thus, luminal cell apical expression of CEA is seen in well-differentiated tumors and, in contrast, cytoplasm expression is seen in poorly differentiated tumors [28]. The tumor cell phenotype correlates with tumor aggressiveness and biological behavior in several cancers. The expression of CD10 suggests colorectal adenocarcinoma with small intestinal differentiation, which is associated with higher venous invasion than large intestinal phenotype of colorectal adenocarcinoma [29]. The diffuse cytoplasmic expression of CEA and the confined expression of CD10 seen in clear cell areas may indicate that these clear cell components harbor greater malignant potential.

Generally, an accumulation of glycogen, mucin, and lipid, as well as enteroblastic differentiation, are well -known examples of the etiology or substances of clear cells in HE specimens. Colorectal tubular adenoma and adenocarcinoma with clear cell components were reported as tubular adenoma with clear cell change (TAC) and CCA, respectively [2-26]. In TAC, an accumulation of glycogen, mucin, and enteroblastic differentiation have never been verified by PAS, Alcian blue staining, or AFP immunostaining [2-9]. Case 1 is negative for those stains, in accord with previous TAC reports. In CCA, on the other hand, some cases are either positive for PAS [2, 11, $13,15,17,21]$, Alcian blue staining [15], or AFP immunohistochemistry [21]; however, other cases are negative for these stains $[3,10,12,14,19,20,26]$. It seems that some heterogeneity exists among CCA cases [2, 3, 7, 10-26]. Case 2 is negative for PAS, Alcian blue staining, and AFP immunostaining and corresponds to previously reported negative-result cases. The pathogenesis of TAC and some CCA cases, including our cases, remains unclear. It may be more appropriate to diagnose Case 2 and those previously reported negative-result cases as tubular adenocarcinoma with clear cell change, corresponding with the malignant counter part of TAC, rather than CCA. 
Electron microscopic examination revealed multiple cytoplasmic lipid-like vacuoles in the clear cells of both cases, and this finding corresponded to previous reports $[3,5,10-12]$. These vacuoles were described as autolysis or elution of glycogen granules during processing or fixation $[5,10]$, glycogen-like material with lipid to a lesser extent [11], and degeneration due to lipid accumulation [6, 9]. Miyasaka et al. [9] recently reported one case of TAC positive for adipophilin immunostaining and described that lipid accumulation might be responsible for its clear cell nature. In our report, Case 1 was negative for adipophilin but case 2 showed focal positive staining for it, which caused us to consider lipid accumulation; however, the immunoelectoron microscopy results were mostly negative for adipophilin. Bressenot et al. [20] reported a CCA and described that they could not detect glycogen in formalin sections but found it in frozen sections. In our study, we could not determine what caused the clear cells in the colorectal tumors; however, autolysis or carbohydrate elution remain possible explanations.

\section{Conclusions}

We report two colorectal tumors with a clear cell component. Accompanying components of conventional tubular adenoma or adenocarcinoma helped us to evaluate the atypia of the clear cells. Differences in staining results for CEA and CD10 were observed and the clear cell component might harbor malignant potential. We tested for the well-known causes of clear cells; however, none were detected. An electron microscopic examination found multiple cytoplasmic lipid-like vacuoles in the clear cell component; however, they were largely negative for adipophilin by immunoelectron microscopy. The causes of clear cells in the colorectal region remain uncertain.

\section{Abbreviations}

CCA: Clear cell adenocarcinoma; CEA: carcinoembryonic antigen; LI: Labeling index; PAS: Periodic acid-Schiff; PAS-D: PAS diastase; TAC: Tubular adenoma with clear cell change

\section{Acknowledgements}

We acknowledge Takashi Yao, professor of Juntendo University, for reviewing our case and giving us important diagnostic advice.

\section{Funding}

None.

\section{Availability of data and materials}

The datasets used and analyzed during the current study are available from the corresponding author upon reasonable request.

\section{Authors' contributions}

YO made substantial contributions to the conception and design of the study and drafted the manuscript. TK, HK, MA, and KO assisted in the analysis and interpretation of the data. JW and SU made substantial contributions to the acquisition of data. HN and TD critically revised the manuscript. All authors gave final approval for this version to be published.

\section{Ethics approval and consent to participate}

Our study was carried out according to the ethical guidelines of the Declaration of Helsinki. It was approved by the institutional review board of Oita University Hospital, which determined that our retrospective study did not require additional informed consent. We removed any details that might disclose the identities of the subjects.

\section{Consent for publication}

Not applicable.

\section{Competing interests}

The authors declare that they have no competing interests.

\section{Publisher's Note}

Springer Nature remains neutral with regard to jurisdictional claims in published maps and institutional affiliations.

\section{Author details}

${ }^{1}$ Departments of Diagnostic Pathology, Faculty of Medicine, Oita University, 1-1, Idaigaoka, Hasama-machi, Yufu City 879-5593, Japan. ²Departments of Gastroenterology, Faculty of Medicine, Oita University, Yufu city, Japan.

${ }^{3}$ Division of Clinical Laboratory, Oita Prefectural Hospital, Oita city, Japan.

Received: 3 January 2019 Accepted: 28 April 2019

Published online: 10 May 2019

\section{References}

1. Kwon TJ, Ro JY, Mackay B. Clear-cell carcinoma: an ultrastructural study of 57 tumors from various sites. Ultrastruct Pathol. 1996;20:519-27.

2. $\quad$ Reed R, Love G, Harkin J. Consultation case. Am J Surg Pathol. 1983;7:597601.

3. Jewell LD, Barr JR, McCaughey WT, Nguyen GK, Owen DA. Clear-cell epithelial neoplasms of the large intestine. Arch Pathol Lab Med. 1988;112: 197-9.

4. Suzuki H, Ohta S, Tokuchi S, Moriya J, Fujioka Y, Nagashima K. Adenoma with clear cell change of the large intestine. J Surg Oncol. 1998;67:182-5.

5. Domoto H, Terahata S, Senoh A, Sato K, Aida S, Tamai S. Clear cell change in colorectal adenomas: its incidence and histological characteristics. Histopathology. 1999;34:250-6.

6. Eloy C, Lopes JM, Faria G, Moreira H, Brandao A, Silva T, et al. Clear cell change in colonic polyps. Int J Surg Pathol. 2009:17:438-43.

7. Shi C, Scudiere JR, Cornish TC, Lam-Himlin D, Park JY, Fox MR, et al. Clear cell change in colonic tubular adenoma and corresponding colonic clear cell adenocarcinoma is associated with an altered mucin core protein profile. Am J Surg Pathol. 2010:34:1344-50.

8. Yao T. Adenoma of clear cell change. Pathol Clin Med. 2016;34:1072-4.

9. Miyasaka C, Ishida M, Ohe C, Uemura Y, Ando Y, Fukui T, et al. Tubular adenomas with clear cell change in the colorectum: a case with four lesions and a review of the literature. Pathol Int. 2018:68:256-8.

10. Hellstrom HR, Fisher ER. Physaliferous variant of carcinoma of colon. Cancer. 1964;17:259-63.

11. Watson PH. Clear-cell carcinoma of the anal canal: a variant of anal transitional zone carcinoma. Hum Pathol. 1990;21:350-2.

12. Rubio CA. Clear cell adenocarcinoma of the colon. J Clin Pathol. 1995:48: 1142-4.

13. Furman J, Lauwers GY. Clear cell change in colonic adenocarcinoma: an equally unusual finding. Histopathology. 1999;35:476-7.

14. Braumann C, Schwabe M, Ordemann J, Jacobi CA. The clear cell adenocarcinoma of the colon: case report and review of the literature. Int J Color Dis. 2004;19:264-7.

15. Mallik AA, Katchy KC. Clear cell adenocarcinoma of the rectum. Med Princ Pract. 2005:14:58-60.

16. Ko YT, Baik SH, Kim SH, Min BS, Kim NK, Cho CH, et al. Clear cell adenocarcinoma of the sigmoid colon. Int J Color Dis. 2007;22:1543-4.

17. Hao LS, Zhu X, Zhao LH, Qian K, Zhou Y, Bu J, et al. Clear cell adenocarcinoma of colorectum: a case report and review of the literature. Acta Gastroenterol Belg. 2007;70:235-8.

18. Barisella M, Lampis A, Perrone F, Carbone A. Clear cell adenocarcinoma of the colon is a unique morphological variant of intestinal carcinoma: case report with molecular analysis. World J Gastroenterol. 2008;14:6575-7. 
19. Soga K, Konishi H, Tatsumi N, Konishi C, Nakano K, Wakabayashi N, et al. Clear cell adenocarcinoma of the colon: a case report and review of literature. World J Gastroenterol. 2008;14:1137-40.

20. Bressenot A, Marcon N, Montagne K, Plenat F. Clear cell adenocarcinoma: a rare variant of primary colonic tumour. Int J Color Dis. 2008;23:137-8.

21. Furuya $Y$, Wakahara T, Akimoto H, Kishimoto T, Hiroshima $\mathrm{K}$, Yanagie $\mathrm{H}$, et al. Clear cell adenocarcinoma with enteroblastic differentiation of the ascending colon. J Clin Oncol. 2011;29:e647-9.

22. Barrera-Maldonado CD, Wiener I, Sim S. Clear cell adenocarcinoma of the colon: a case report and review of the literature. Case Rep Oncol Med. 2014; 2014:905478.

23. Wang W, Li X, Qu G, Leng T, Geng J. Primary clear cell adenocarcinoma of the colon presenting as a huge extracolic mass: a case report. Oncol Lett. 2014;8:1873-5.

24. Thelin C, Alquist CR, Engel LS, Dewenter T. Primary clear cell adenocarcinoma of the colon: a case report and review. J La State Med Soc. 2014;166:143-8.

25. Remo A, Grillo F, Mastracci L, Fassan M, Sina S, Zanella C, et al. Clear cell colorectal carcinoma: time to clarify diagnosis. Pathol Res Pract. 2017;213: 447-52.

26. Tochio T, Mukai K, Baba Y, Asakawa H, Nose K, Tsuruga S, et al. Early stage clear cell adenocarcinoma of the colon examined in detail with imageenhanced endoscopy: a case report. Clin J Gastroenterol. 2018;11:465-9.

27. Yano S, Kashima K, Daa T, Urabe S, Tsuji K, Nakayama I, et al. An antigen retrieval method using an alkaline solution allows immunoelectron microscopic identification of secretory granules in conventional epoxyembedded tissue sections. J Histochem Cytochem. 2003;51:199-204.

28. O'brien M, Zamcheck N, Burke B, Kirkham S, Saravis C, Gottlieb L. Immunocytochemical localization of carcinoembryonic antigen in benign and malignant colorectal tissues: assessment of diagnostic value. Am J Clin Pathol. 1981;75:283-90.

29. Yao T, Tsutsumi S, Akaiwa Y, Takata M, Nishiyama K, Kabashima A, et al. Phenotypic expression of colorectal adenocarcinomas with reference to tumor development and biological behavior. Jpn J Cancer Res. 2001;92:755-61.

Ready to submit your research? Choose BMC and benefit from:

- fast, convenient online submission

- thorough peer review by experienced researchers in your field

- rapid publication on acceptance

- support for research data, including large and complex data types

- gold Open Access which fosters wider collaboration and increased citations

- maximum visibility for your research: over $100 \mathrm{M}$ website views per year

At $\mathrm{BMC}$, research is always in progress.

Learn more biomedcentral.com/submissions 